\title{
Intimidade das confidências
}

\section{Eliane Vasconcellos}

Resumo Traçamos um breve histórico do gênero epistolar, para depois contextualizar as cartas dentro dos arquivos pessoais de escritores, dando ênfase ao problema dos direitos autorais da correspondência. Palavras-chave carta; arquivos pessoais; direito autoral.

Abstract We propose to track a brief history of the letter as a gender. Afterwards, we will contextualize the letters in the personal files of the writers, giving emphasis on the problem of authors' rights, when correspondence is regarded. Keywords letter; personal files; copyright. 
Escrever cartas é mostrar-se, chamar a atençāo, presentificar a imagem do outro.

[Michel Foucault]

Ao consultarmos os dicionários, verificamos que a palavra carta aparece como núcleo de mais de 79 locuções. Etimologicamente este vocábulo provém do latim charta,ae ou carta,ae: "folha de papiro preparada para receber a escrita; folha de papel (feito antigamente da entrecasca do papiro)" empréstimo antigo e latinizado do grego khártés, ou "folha de papiro ou de papel, por extensão, escrita, obra". Interessa-nos a carta na sua acepção mais usual: a de mensagem, manuscrita ou impressa, a uma pessoa ou a uma organização, para comunicar-lhe algo. Por extensão, mensagem, "fechada num envelope, geralmente endereçado e frequentemente selado", segundo o Dicionário Houaiss da língua portuguesa. No passado, o selo era a marca do sigilo.

A carta aproxima os ausentes e é caracterizada pela espontaneidade e, teoricamente, sem intuito de alcançar posteridade. Alguns autores publicam-nas em vida, como Paul Claudel e André Gide, isto porque sua função vai além do ato da escrita e da recepção.

No gênero correspondência, como no lírico, o sujeito da enunciação é o mesmo que o do enunciado. Assim, para Manuela Parreira da Silva,

[...] queimar uma carta significa destruir o próprio vínculo (amoroso) que ela suporta; conservar as cartas de alguém é preservar a sua própria corporalidade; devolvê-las corresponde a negar-se como destinatário, como pessoa, a negar a sua história; tirar e guardar uma cópia dela pode ser uma forma de autoafirmação; assim como sabê-la chegada ao destinatário e até tornada do domínio público pode ser vivido como uma manifestação de poder.'

O uso da carta já se manifestava entre os povos antigos. Escrever cartas era prerrogativa das pessoas de classes sociais mais altas e dos comerciantes; muitas vezes

1 SILVA, Manuela Parreira. Para uma teoria da prática epistolar pessoana. In: Correspondências. Lisboa: Colibri, 1998, p. 139. 
elas eram ditadas aos "escravos secretários", e aquele que a ditava colocava uma inscrição final de próprio punho. Gregos e romanos escreviam em lâminas ou tabletes de cera e entregavam a um escravo para levá-las ao destinatário. A escrita, feita por meio de um estilete, era gravada em um só lado da lâmina, que era envolvida por uma fita, contendo, no extremo, o carimbo; na parte externa, gravava-se o endereço. Posteriormente foi adotado o papiro ou charta, conhecida desde Alexandre Magno, a qual se compunha de duas folhas atravessadas por um cordão, que terminava em nó, com um carimbo.

Os escravos encarregados da correspondência chamavam-se amanuenses ou epistolis a manu. Durante a Idade Média, o material empregado foi o pergaminho, tendo sido substituído pelo papel no século xiv. O sinete, ou timbre do anel, era feito em cera de abelha e, depois dessa época, o lacre passou a ter voga.

Como se pode observar pelas características expostas, a carta missiva vem sempre envolta em sigilo: ora envolvida por uma fita, ora marcada com um carimbo, sinete ou lacre. Hodiernamente, estes foram substituídos pelo envelope fechado, muitas vezes acrescido da observação "confidencial", não podendo ser abertas por outrem, que não o destinatário; em caso contrário, constitui-se uma contravenção. ${ }^{2}$

As cartas têm caráter íntimo e/ou confidencial. Logo, as informações ali registradas fazem parte do espaço privado, inviolável, onde os envolvidos são o autor ou signatário, a pessoa a quem é dirigida - o destinatário, e muitas vezes uma terceira pessoa, da qual se fala.

Numa retrospectiva ao mundo ocidental, no Segundo Livro de Samuel, capítulo 11, encontramos a carta; no Livro de Ester, capítulo 8, versículo 10, lemos: "Escreveu-se em nome do rei Assuero e se selou com o anel do rei; as cartas foram enviadas por intermédio de correios montados em ginetes”. No antigo Egito já se encontrava a representação das cartas em suas pinturas. As mais antigas cartas datam do século IV a.C., e podemos citar as de Isócrates e as de Epicuro e, no mundo romano, tornaram-se célebres as epístolas como as de Cícero e de

2 Lei 6.538 art. 10 - Não constitui violação do sigilo da correspondência postal a abertura de carta: I - endereçada a homônimo, no mesmo endereço; II - que apresente indícios de conter objeto sujeito a pagamento de tributos; III - que apresente indícios de conter valor não declarado, objeto ou substância de expedição, uso ou entrega proibidos; IV - que deva ser inutilizada, na forma prevista em regulamento, em virtude de impossibilidade de sua entrega e restituição. 
Horácio. Cícero queria dá-las a lume ainda em vida, projeto que foi abortado e, pelo que se crê, muitas das cartas publicadas teriam sido censuradas pelo autor. Dos anos 50-52 d.C., temos as Epístolas de Paulo, para serem lidas nas comunidades cristãs e nas quais o apóstolo respondia às dúvidas e ajudava a esclarecer pontos do cristianismo.

Ao contrário do que ocorre nos dias atuais, na Idade Média uma mensagem de caráter confidencial não era redigida, era transmitida oralmente. E o ato de ditar ou redigir uma carta estava reservado a uma minoria, àqueles que tinham o domínio do latim, idioma utilizado na correspondência até o século XIII.

$\mathrm{Na}$ Idade Média, a carta adquiriu um estatuto diferente: ela se constitui em matéria a ser ensinada, com regras particulares. Deveriam ter uma estrutura paralela à do discurso, tal como nos manuais de retórica. Compreendia cinco partes: salutatio (fórmula de saudação ao destinatário, seguido ocasionalmente de seu título), exordium, narratio, petitio e conclusio. Estas partes vão depois se simplificar e, de certa forma, permanecem até hoje. Teremos então uma introdução, a apresentação da mensagem, a narração propriamente dita e a despedida, sendo que a introdução e a despedida constituíram, em alguns momentos da história, verdadeiros exercícios de preciosismo.

Há correspondências que se tornaram famosas. Temos as cartas trocadas entre Abelardo e Heloísa; em 1350, Petrarca começa a publicar suas cartas, tendo o cuidado de encobrir o nome dos destinatários para não comprometê-los; no século XVII, a epistolografia vai atingir grande destaque, principalmente na França, onde os salões terão importância fundamental para a difusão das cartas. Involuntaria-

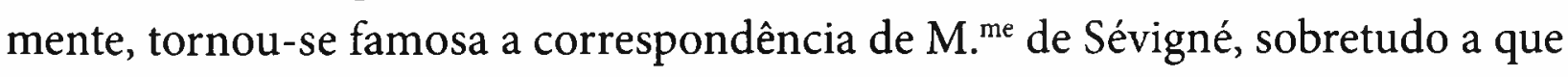
foi trocada com sua filha (que se havia casado e mudado para a Provence), postumamente publicada com o título de Lettres (1726). Em 1669, publicam-se em Paris as famosas Lettres portugaises (Cartas portuguesas), atribuídas à freira Mariana Alcoforado, que, por volta de 1665, teria conhecido em Portugal o Marquês de Chamilly, por quem se apaixonou. Quando este regressou para a França, recebeu dela cinco cartas.

Até o século $\mathrm{xV}$ os documentos eram copiados à mão e circulavam entre um grupo restrito de pessoas. Com o advento da imprensa, os textos passam a ser reproduzidos com mais facilidade, o que permitiu perceber-se que quem possuía uma 
cópia do documento nāo era o proprietário intelectual deste; de fato, o detentor desta propriedade era o autor, o que dará origem ao copyright e droit d'auteur.

Na segunda metade do século XVII, para auxiliar aqueles que não dominavam a arte da epistolografia, proliferam as publicações de manuais e secretários epistolares, que tinham por objetivo ditar regras de bom-tom para se escrever corretamente. Estas publicações traziam modelos de cartas, sugeriam formas de cabeçalhos e de despedidas; e os últimos levavam esta denominação em alusão àqueles que possuíam um secretário, para o qual ditavam as cartas. Coube ao escritor do renascimento espanhol Antonio de Torquemada a primazia de publicar, em 1574, um Manual de escribientes, que estabelecia regras retóricas para o desempenho do ofício de escrevente.

De 1598 é Les fleurs du bien dire, que trazia 72 modelos de cartas. Jean Puget de la Serre vai nos dar, em 1640, o Le secrétaire à la mode, cujo subtítulo "méthode facile d'écrire selon le temps diverses lettres de compliments amoureuses et morales... augmenté des élégances françaises accommodées au langage du temps" nos dá bem a ideia do objetivo da obra. Serre faz um inventário dos diferentes tipos de carta e propõe uma retórica do gênero epistolar. Em 1684, François de Fenne vai publicar Secrétaire à la mode réformé, com o longo subtítulo de "ou le Mercure nouveau, contenant les lettres choisies des plus beaux esprits de ce temps, avec une nouvelle instruction à écrire des lettres, et vi entretiens de la civilité"

Em 1845, J. I. Roquette publicou em Paris o Código do bom-tom ou regras da civilidade e de bem viver no século XIX. O volume apregoa as regras do bem viver, é repleto de narrativas edificantes e destina o capítulo 13 às cartas. Aí o autor dá vários conselhos sobre esta arte e chega mesmo a recomendar a leitura de Le style épistolaire. Na parte relativa às regras gerais para a composição de cartas, esclarece que as normas que vai ditar são para as cartas particulares que "se escrevem entre amigos, ou pessoas de conhecimento, sem tenção que se publiquem". ${ }^{3} \mathrm{De}$ acordo com Roger Chartier, é pouco provável que estes manuais tenham servido aos leitores populares, mas possuí-los era "espécie de enobrecimento cultural". ${ }^{4}$

3 ROQUETE, J.I. Código do bom-tom ou regras da civilidade e de bem viver no séc. XIX. Organização de Lília M. Schwarcz. São Paulo: Companhia das Letras, 1997, p. 280.

4 CHARTIER, Roger. As práticas da escrita. In: ARIES, Philippe; CHARTIER, Roger. História da vida privada. São Paulo: Companhia das Letras, 1991, v. 3, p. 116 
Paralelamente, encontramos o aparecimento dos escritores públicos, destinados a redigir mensagens para pessoas sem instrução, aspecto este explorado recentemente no filme brasileiro Central do Brasil. É o que se vê também no conto "Uma vela para o diabo", em Tutameia, de Guimarães Rosa.

No Brasil, no século xix e até meados do século xx, foram comuns estes florilégios como o Novo manual epistolar ou secretário de cartas particulares e Cartas de peditórios matrimoniais, com modelos de declarações de amor com o objetivo honesto de matrimônio. Sob o pseudônimo D. Juan de Botafogo, Figueiredo Pimentel publica, em 1897, o Manual do namorado, com o longo subtítulo "contendo a maneira de agradar às moças; fazer declarações de amor; vestir com elegância; estar à mesa; em bailes, em passeios e tudo quanto se usa na alta sociedade", que revela o objetivo e a intenção do livro. ${ }^{5}$ Incluem-se aí 100 cartas de namoro. Estes manuais de alguma forma persistem até hoje, mesmo com o advento da internet. Se, por curiosidade, realizar-se uma pesquisa em um site de busca pela expressão "como escrever cartas". serão encontradas cerca de 1.520.00o incidências.

A carta vai ser objeto também na pintura. Diversos quadros de Johannes Vermeer, pintor holandês do século XVII, por exemplo, têm por temática a mulher jovem lendo ou escrevendo carta: Moça escrevendo uma carta, Carta de amor, Moça lendo uma carta à janela, Mulher de azul lendo uma carta. Moça e sua servente segurando uma carta, Mulher lendo uma carta, ${ }^{6}$ para destacar algumas.

Podemos ter cartas dirigidas a um destinatário real ou a um destinatário fictício. No século XVIII, vemos o apogeu do romance epistolar como gênero literário. Entre eles citamos: La nouvelle Heloïs, La paysanne pervertie, Lettres de la marquise de $M$ au comte de $R$, Les liaisons dangereuses. Robert Darnton, analisando o romance de Rousseau Nova Heloísa, diz:

Muitos leitores da Nova Heloísa acreditavam e queriam crer na autenticidade das cartas. Mesmo o interlocutor sofisticado do segundo prefácio, o "prefácio dialogado", confessa-se "atormentado" pela necessidade de saber se Júlia existiu realmente, e ele

5 Este manual pode ser encontrado na Biblioteca Nacional (Rio de Janeiro) em uma edição de 1953.

6 Os quadros estão disponiveis em http://gallery.euroweb.hu/html/t/terborch/2/woman_r.html>. Acesso em: 27 de março de 2007. 
faz toda a discussão do romance girar em torno da interrogação: "Essa correspondência é real, ou é uma ficção?">

A carta, enquanto gênero, foi e é vista à margem da literatura, uma vez que se produziu longe do intuito primeiro - o literário -, posição assumida no início do século Xx por Lanson, ${ }^{8}$ um dos estudiosos de correspondência. Como salientou Maria José de Queiroz, "o escritor cultiva inicialmente o gênero, alheio à ideia da fama e à tentação da glória. Não há, advirta-se, na tradição epistolográfica, um corpus coerente que favoreça uma retrospectiva referencial, exata e pertinente."

A história do Brasil começou com a carta de Pero Vaz de Caminha, para falar ao Rei de Portugal sobre as belezas da nova terra e a descrição de seus habitantes, centrando o seu olhar na docilidade e no exotismo dos gentios, bem como na grande possibilidade de eles serem catequizados. $O$ relato chama a atenção também para o potencial mercantilista da nova terra, tendo ficado famoso o trecho transcrito abaixo:

Nela, até agora, não pudemos saber que haja ouro, nem prata, nem coisa alguma de metal ou ferro; nem lho vimos. Porém a terra em si é de muito bons ares, assim frios e temperados, como os de Entre Doiro e Minho, porque neste tempo de agora os achávamos como os de lá.

Águas são muitas; infindas. E em tal maneira é graciosa que, querendo-a aproveitar, dar-se-á nela tudo, por bem das águas que tem. ${ }^{10}$

Como observou Ferdinand Denis (1798-1846), "Graças ao raro talento de observação de que era dotado, graças sobretudo à fácil ingenuidade do seu estilo, o Brasil teve um historiador no próprio dia do seu descobrimento". Este documento, que

7 DARNTON, Robert. A leitura rousseauista e um leitor "comum" do século XVIII. In: CHARTIER, Roger. Práticas da leitura. São Paulo: Estaçāo Liberdade, 1996.

8 LANSON, Gustave. Sur la littérature épistolaire. In: Essais de méthode, de critique et d' histoire littéraire. Paris: Hachette, 1965.

9 QUEIROZ, Maria José de. Prefácio. In: BARBOSA, Rui. Cartas à noiva. Rio de Janeiro: Fundação Casa de Rui Barbosa/ Civilização Brasileira, 1982, p. 10.

10 CORTESÃO, Jaime. A carta de Pero Vaz de Caminha. Rio de Janeiro: Livros de Portugal, 1943, p. 240. 
se encontra na Torre de Tombo, só se tornou público em 1817, por iniciativa do padre Manuel Aires do Casal. Trata-se de uma narrativa do ponto de vista externo, ou seja, o de um estrangeiro que aqui ficou somente uma semana e relatou o que viu. Do mesmo ângulo é a carta de Américo Vespúcio e Mestre João, em que, também, não há depoimento da parte contrária, isto é, dos habitantes da terra.

Serão também de importância fundamental para a construção da nossa identidade as cartas escritas pelos jesuítas que acompanharam a expedição na qual vinha o primeiro governador geral, Tomé de Sousa. Esta primeira missão era chefiada pelo padre Manuel da Nóbrega e seu objetivo era catequizar os nossos silvícolas. Para acompanhar as atividades dos missionários que se encontravam espalhados pelos quatro cantos do mundo, a Companhia de Jesus instaurou um método seguro que consistia na remessa de cartas com relato das atividades desenvolvidas. Para se ter uma ideia desta rede de informações, entre 1524 e 1556, Santo Inácio redigiu 6.815 cartas. Ao contrário da carta de Caminha, as cartas escritas pelos jesuítas seguiam a tradição das epístolas de Paulo: eram copiadas e lidas nas diferentes localidades onde os missionários se encontravam. Essas cartas, diz Sheila Moura Hue, "escritas num tom familiar, coloquial, procurando uma comunicação fácil e direta, sem artifícios de retórica ou citações eruditas, mais próximas do diálogo do que do discurso formal", garantiram-lhes sucesso quando de sua edição. Entretanto, esclarece ainda a autora, estas cartas não foram publicadas em sua versão original, foram re-escritas, pois os textos "pouco edificantes" eram censurados, o que ocorreu principalmente com as cartas remetidas do Brasil." Se comparamos as missivas jesuíticas com a de Caminha, percebemos que já se avança mais um passo. Não são cartas escritas por habitantes da terra, o olhar estrangeiro ainda está presente, mas agora é o do estrangeiro que aqui permaneceu.

De 1553 é a carta-relatório de Tomé de Sousa, na qual ele descreve ao rei tudo o que fez e viu nas diversas capitanias. Em 1787, Thomas Jefferson, então ministro estadunidense na França, escreve uma carta a John Jay, na qual transcreve parte da carta recebida pelo estudante brasileiro José Joaquim da Maia, pedindo para o governo dos Estados Unidos auxiliar o Brasil numa revolução contra Portugal. Eram os preparativos para a Inconfidência Mineira, mas é outra carta - a de

11 Primeiras cartas do Brasil. Tradução, introdução e notas de Sheila Moura Hue. Rio de Janeiro: Zahar, 2006. 
Joaquim Silvério dos Reis encaminhada ao Visconde de Barbacena - que delata os preparativos da Inconfidência. No mesmo dia em que a carta foi entregue, 19 de abril de 1789, Tiradentes foi preso.

Ligadas também, embora indiretamente, ao movimento chefiado por Tiradentes, são as famosas Cartas chilenas, conjunto de treze epístolas, escritas em versos brancos, que versam sobre a vida do governador de Vila Rica; trata-se da mais importante sátira do século XVIII, daí os seus personagens aparecerem ocultos sob pseudônimos. Circularam manuscritas, tendo como signatário um certo Critilo (Tomás Antônio Gonzaga) e, como destinatário, Doroteu (Cláudio Manuel da Costa); o governador de Minas Gerais, Dom Luís da Cunha Pacheco Meneses, era o personagem Fanfarrão Minésio; o Brasil era tratado por Chile e a capital de Minas, Vila Rica, por Santiago. O Brasil passa agora a ser olhado por dentro.

Poderíamos também registrar algumas cartas importantes no nosso período imperial e republicano, mas este não é o nosso objetivo. Valemo-nos deste pequeno histórico para ressaltar a importância da correspondência no âmbito dos estudos culturais e literários.

André Maurois, na introdução que escreveu para a coletânea de cartas de Lord Byron, afirma:

[...] há três espécies de autores de carta: aqueles que delas se servem para expor ideias; os que, tendo poucos fatos a contar, transformam em maravilhoso relatório os mínimos incidentes de uma vida especialmente monótona, e adornam qualquer evento com o prestígio da forma; e aqueles, finalmente, que escrevem porque não podem fazer outra coisa, e lançam o próprio eu comovente e vivo na sua correspondência.

Na sua opinião, o maior carteador seria Taine, seguido de M. ${ }^{\text {me }}$ Sévigné e Byron. ${ }^{12}$ A carta torna-se propriedade do destinatário, e a este cabe optar quanto ao destino que dará ao documento: ou lê e destrói, ou guarda consigo, muitas vezes deixando-as para a posteridade. Neste caso, cabe aos seus herdeiros defender a reputação do morto. Normalmente, os que guardam cartas são pessoas letradas, que têm consciência do valor informativo nelas contido. A missiva em sua origem

12 Apud QUEIROZ, Maria José de."Prefácio". In: BARBOSA, Rui. Op. cit., p. 11. 
é um texto que não deve ser publicado, mas nem sempre se respeita este estatuto, pois muitas vezes é um documento rico de informações históricas, biográficas, literárias e artísticas, mesmo que apresentadas de forma fragmentada. Robert $\mathrm{C}$. Angell e Ronald Freedman, ao classificar as cartas, enquadram-nas como "documentos expressivos", junto com as biografias, os diários, as autobiografias, e dizem que elas são o tipo de documento expressivo mais acessível e variam de acordo com o ambiente cultural dos que as escrevem. ${ }^{13}$ Quando tomadas como documento, elas devem ser comparadas a outras cartas e a outros documentos, porque se deve desconfiar sempre da sinceridade epistolar.

No momento em que é publicada, a carta adquire um novo status: este documento que supostamente diz a verdade, este testemunho da esfera do privado passa a ser olhado por todos e a crítica pode agora opinar sobre as informações que ali aparecem representadas. Algumas vezes seus autores mudam de opinião ou de pontos de vista e cartas escritas em determinada época são até repudiadas mais tarde. $\mathrm{Na}$ carta o signatário fala ao seu interlocutor como se este estivesse presente e, mais do que isto, por detrás da máscara, diz certas verdades ou expõe certos pensamentos. Mudando de acordo com a época, espera-se que o seu conteúdo traga novidades do cotidiano, da vida política e pessoal, reflexões, confidências e expressões de sentimentos. Há um status peculiar entre o autor (signatário) e o leitor (destinatário), tendo muitas vezes valor de crônica.

Juridicamente, no Brasil, a carta vem definida na Lei 6.538, de 1978, como:

[...] objeto de correspondência, com ou sem envoltório, sob a forma de comunicação escrita, de natureza administrativa, social, comercial, ou qualquer outra, que contenha informação de interesse específico do destinatário.

As cartas dirigidas a um destinatário real estão envolvidas em dois aspectos: o documental e o literário. Elas são hodiernamente consideradas como parte da obra de um autor, pois é comum encontrarmos a correspondência publicada junto à

13 ANGELL, Robert C.; FREEDMAN, Ronald. A utilizaçāo dos documentos, arquivos, dados censitórios e índices. In: ANGELL, Robert Cooley. A pesquisa na psicologia social. Trad. de Gastão Jacinto Gomes. Rio de Janeiro: FGV, 1974, p. 294-5 
obra completa. Como já ressaltamos, apesar de não haver na correspondência intenção artística, ela pode ser considerada um gênero literário, isto é, ganha uma pátina estético-literária.

Durante muito tempo, a correspondência permaneceu sepultada nos arquivos públicos ou privados e recentemente passou a ter valor como fonte primária. Os pesquisadores têm-se conscientizado de que podem encontrar nela dados relevantes, além de ser um importante documento para revelar o processo criativo. Não é sem razão que os atuais estudos de crítica genética se valem cada vez mais da escrita epistolar como forma de desvendar as particularidades da criação literária. Nas palavras de Marcos Antonio de Moraes, o diálogo epistolar é um "canteiro de obras - os 'arquivos da criação' - onde se podem divisar elementos seminais para a compreensão de um ideal estético ou se descobrem intenções capazes de explicitar passos obscuros do arte-fazer" ${ }^{14}$

No nosso caso específico, estamos falando das cartas missivas que se encontram nos arquivos privados de escritores. ${ }^{15} \mathrm{Em}$ momento algum elas perdem suas características: não deixam de ser cartas e fixam um momento, mas transformam-se em documento de pesquisa. O nosso maior missivista, Mário de Andrade, já ressaltou este ponto: "Tudo será posto a lume um dia, por alguém que se disponha a realmente fazer a História. E imediato, tanto correspondência como jornais e demais documentos não 'opinarão' como nós, mas provarão a verdade".16

Se, de um lado, Mário reconhece a importância da correspondência como fonte documental, de outro sabe também que se trata de uma faca de dois gumes. Sendo um defensor da privacidade, diz a Manuel Bandeira: "As cartas que mando pra você são suas. Se eu morrer amanhã não quero que você as publique" ${ }^{17}$ Como sabemos, Manuel Bandeira felizmente não seguiu a recomendação do amigo; transgrediu seu

14 MORAES, Marcos Antonio de. Cartas, um gênero híbrido e fascinante. In: Jornal da Tarde, São Paulo, 28 out. 2000. Caderno Sábado.

15 "Conjunto de documentos acumulados em decorrência das atividades de pessoas físicas e jurídicas de direito privado, depositados ou não em instituições públicas." In: CAMARGO, Ana Maria et alii (Org.). Dicionário de terminologia arquivística. São Paulo: Associação dos Arquivistas Brasileiros, 1996.

16 ANDRADE, Mário de. Fazer a História. In: Folha da Manhã, São Paulo, 28 ago. 1944. ("Mundo Musical").

17 Correspondência de Mário de Andrade \& Manuel Bandeira. Organização, introdução e notas de Marcos Antonio de Moraes. São Paulo: Edusp/IEB, 2000, p. 182. 
conselho e será o primeiro a publicar-lhe as cartas, suprimindo-lhes, porém, alguns trechos para preservar as confidências de Mário. Deixemos o poeta falar:

Possuo cartas de Mário indevassáveis devido à intimidade das confidências (é o caso das duas cartas em que ele me relatou a breve ligação com a mulher que lhe inspirou o "Girassol da madrugada") ou à rudeza de certos juízos pessoais, fruto muitas vezes de irritações momentâneas. Todos fizemos isso e, arrependidos que estamos, pensamos com inquietação numa possível leviandade dos destinatários.

Nas que aqui se vão ler, cartas tão esclarecedoras da obra de Mário, da sua maneira de trabalhar, da sua visão, tão pessoal, da vida e da literatura, da música e das artes plásticas, uma ou outra passagem seria indiscreto revelar sem a cautela de alguns cortes. Assim procedendo, atendo à confiança com que o grande poeta escreveu e me mandou tantas páginas admiráveis, muitas não inferiores às melhores que publicou em vida. ${ }^{18}$

Esta atitude de Manuel Bandeira, de respeito e de ética com relação à publicação das cartas de Mário, vai ser seguida pela maioria de seus amigos. Oneida Alvarenga também suprime nomes; Pedro Nava não publica algumas cartas e, ao doá-las ao Arquivo-Museu de Literatura Brasileira da Fundação Casa de Rui Barbosa, entregou-as lacradas.

Voltando à explicação de Manuel Bandeira, podemos observar que o poeta, ao censurar a correspondência do amigo, levou em conta os seguintes aspectos: intimidade das confidências, rudeza de certos juízos pessoais e cautela, sem prejuízo do valor literário da correspondência. Bandeira tomou esta atitude por saber que em uma carta o signatário raramente faz restrições ao seu pensamento, ele se coloca a nu diante do destinatário. O poeta, ao fazer cortes, estava preservando também o direito à intimidade.

Por se tratar de um discurso informal, na carta se expõem ideias e sentimentos que são reduzidos e interpretados por um terceiro - o leitor. Esta é a razão pela qual aqueles que trabalham com correspondências encontradas em arquivos privados devem ter em mente alguns problemas de ordem jurídica e ética, que, de

18 BANDEIRA, Manuel. Prefácio. In: ANDRADE, Mário de. Cartas de Mário de Andrade a Manuel Bandeira. Rio de Janeiro: Organizaçōes Simōes, 1958, p. 8. 
certa forma, encontram suas raízes nas observações feitas por Bandeira ao publicar as cartas de Mário.

No que diz respeito ao aspecto jurídico, salienta-se que as cartas estão protegidas pelo direito de autor, definido por Clóvis Beviláqua como o direito que "tem o autor de obra literária, científica, ou artística de ligar o seu nome às produções do seu espírito e de reproduzi-las. Na primeira relação é manifestação da personalidade do autor, na segunda é de natureza real e econômica".19 A primeira lei sobre este assunto foi sancionada em 1710 pela rainha Anne Studart e, em 1791, a França instituiu o droit d'auteur, direito estabelecido em quase todos os países e que foi tratado na Convenção de Berna de 1886, à qual o Brasil aderiu. Rui Barbosa, em 1893, sobre este assunto assim se pronunciou:

Não dispomos de muito tempo, para ventilarmos a questão moral, jurídica, internacional da propriedade literária, ou direitos autorais, como agora se diz [...]. Aproveitamos, todavia, os poucos instantes, que nos restam para insistir na universalidade legislativa dessa ideia, que a maioria da comissão diz "admitida aqui, rejeitada acolá".20

No Brasil, o direito de autor é recente; sua autonomia jurídica deu-se somente com a Lei 5.988/73, embora o assunto já tivesse merecido atenção no artigo $7^{\circ}$ da Lei Imperial de 1827; ao falar da criação dos cursos jurídicos em São Paulo e em Olinda, diz que "Estes compêndios [...] o governo fará imprimir e fornecer às escolas, competindo aos seus autores o privilégio exclusivo da obra por dez anos"; o artigo 261 do Código Criminal do Império, de 1830, estabelecia pena contra quem "imprimir, gravar, litografar, introduzir quaisquer escritos ou estampas que tiverem sido feitos, compostos ou traduzidos por cidadãos brasileiros, enquanto estes viverem e dez anos depois de sua morte, se deixarem herdeiros" A Constituição de 1891 incluía o direito do autor entre os direitos fundamentais; no artigo 26, lê-se: "Aos autores de obras literárias e artísticas é garantido o direito exclusivo de reproduzi-las, pela

CHAVES, Antônio. Direito de autor. In: Enciclopédia Saraiva do Direito. Rio de Janeiro: São Paulo, 1979, v. 25, p. 107.

20 BARBOSA, Rui. A ditadura de 1893. Rio de Janeiro: Ministério de Educação e Cultura, 1945 (Obras completas, V. 20, 1893, t. 3). 
imprensa ou por qualquer outro processo mecânico. Os herdeiros dos autores gozarão desse direito pelo tempo que a lei determinar" O Código Civil de 1916, artigos 649 e 673, também dispõe sobre o direito de autor. Em 1973 tivemos uma legislação especial sobre este assunto - Lei ${ }^{\circ} 5.988 / 73$, alterada em 1998.

A Constituição brasileira de 1988, na parte "Dos direitos e garantias fundamentais", artigo $5^{\circ}$ inciso $\mathrm{x}$, dispõe sobre a proteção do direito à intimidade: "São invioláveis a intimidade, a vida privada, a honra e a imagem das pessoas, assegurado o direito à indenização pelo dano material ou moral decorrente de sua violação" 21 E o inciso XXVII diz que "aos autores pertence o direito exclusivo de utilização, publicação ou reprodução de suas obras transmissíveis aos herdeiros pelo tempo que a lei fixar"

Do ponto de vista jurídico, o signatário detém o direito autoral da carta; o destinatário possui o direito material, ou seja, ele é dono do suporte, normalmente o papel em que a carta foi escrita, e os dois são protegidos pelo direito à intimidade, assim também como aqueles que são mencionados no texto em questão. ${ }^{22}$ Quando esses documentos são postos sob a guarda de uma instituição, esta não pode autorizar a sua publicação, tendo em vista esses direitos. O artigo 153 do Código Penal diz constituir crime: "Divulgar alguém, sem justa causa, conteúdo de documento particular ou de correspondência confidencial, de que é destinatário ou detentor, e cuja divulgação possa produzir dano a outrem".

A lei que rege os Direitos Autorais é de 19 de fevereiro de 1998 (Lei 9.610/98). No seu artigo $7^{\circ}$, lê-se: "São obras intelectuais protegidas as criações do espírito, expressas por qualquer meio ou fixadas em qualquer suporte, tangível ou intangível,

21 "Pena - detenção, de 1 (um) a 6 (seis) meses, ou multa." Ver também os artigos 184, 185 e 186 do Código penal brasileiro.

22 Conforme salienta Newton Paulo Teixeira dos Santos, o direito à intimidade está diretamente relacionado à inviolabilidade da correspondência: "a carta é um instrumento propício a essa violaçāo, a todo momento em que se revele ou se publique o que o autor da carta, seu destinatário, ou mesmo terceiro, pretendiam preservar". Assim sendo, podemos concluir que o direito da intimidade limita o direito autoral e, assim como o direito autoral é transmitido aos herdeiros, o direito à intimidade também o é. Entretanto, decorridos os 70 anos exigidos para o domínio público, aquilo que poderia ferir a intimidade fica descontextualizado e a "ofensa" perde muito o seu sentido; do mesmo modo, tanto o distanciamento emocional quanto o temporal permitem uma leitura crítica. 
conhecido ou que se invente no futuro". E discrimina em seus incisos quais são estas "obras intelectuais protegidas": os textos de obras literárias, artísticas ou científicas; as conferências, alocuções, sermões e outras obras da mesma natureza; as obras dramáticas e dramático-musicais; as obras coreográficas e pantomímicas, cuja execução cênica se fixe por escrito ou por outra qualquer forma; as composições musicais, tenham ou não letra; as obras audiovisuais, sonorizadas ou não, inclusive as cinematográficas; as obras fotográficas e as produzidas por qualquer processo análogo ao da fotografia; as obras de desenho, pintura, gravura, escultura, litografia e arte cinética; as ilustrações, cartas geográficas e outras obras da mesma natureza; os projetos, esboços e obras plásticas concernentes à geografia, engenharia, topografia, arquitetura, paisagismo, cenografia e ciência; as adaptações, traduções e outras transformações de obras originais, apresentadas como criação intelectual nova; os programas de computador; as coletâneas ou compilações, antologias, enciclopédias, dicionários, bases de dados e outras obras, que, por sua seleção, organização ou disposição de seu conteúdo, constituam uma criação intelectual.

Os artigos $24^{23}, 25,26$ e $27^{24}$ dispõem sobre os direitos morais do autor em relação à obra intelectual que produziu; o artigo 28 esclarece: "Cabe ao autor o direito exclusivo de utilizar, fruir e dispor da obra literária, artística ou científica"; o artigo 29 adverte: "Depende de autorização prévia e expressa do autor a utilização da obra, por quaisquer modalidades"; e o artigo 31 salienta que a autorização conce-

23 São direitos morais do autor: o de reivindicar, a qualquer tempo, a autoria da obra; o de ter seu nome, pseudônimo ou sinal convencional indicado ou anunciado, como sendo o do autor, na utilizaçāo de sua obra; o de conservar a obra inédita; o de assegurar a integridade da obra, opondo-se a quaisquer modificaçōes ou à prática de atos que, de qualquer forma, possam prejudicá-la ou atingi-lo, como autor, em sua reputação ou honra; o de modificar a obra, antes ou depois de utilizada; o de retirar de circulação a obra ou de suspender qualquer forma de utilização já autorizada, quando a circulação ou utilização implicarem afronta à sua reputação e imagem; o de ter acesso a exemplar único e raro da obra, quando se encontre legitimamente em poder de outrem, para o fim de, por meio de processo fotográfico ou assemelhado, ou audiovisual, preservar sua memória, de forma que cause o menor inconveniente possivel a seu detentor, que, em todo caso, será indenizado de qualquer dano ou prejuízo que the seja causado. Por morte do autor, transmitem-se a seus sucessores os direitos a que se referem os incisos I a IV. 
dida pelo autor ou pelo produtor para uma forma de utilização não se estende às demais obras, senão à que está em questão.

O artigo 34 da mesma lei registra: "As cartas missivas, cuja publicação está condicionada à permissão do autor, poderão ser juntadas como documento de prova em processos administrativos e judiciais" (grifo nosso)

O remetente detém o poder de autoria sobre sua correspondência, não levando em conta o valor estético; e, como já mostramos, o artigo $5^{\circ}$, inciso XXVII, da Constituição, dá-lhe o direito de publicação ou reprodução, direito este transferível a seus herdeiros, pelo prazo de 70 anos, a partir de primeiro de janeiro do ano subsequente ao do falecimento do autor (artigo 41 da Lei de Direitos Autorais). ${ }^{25}$ Só depois a carta, como toda a obra de um autor, cai em domínio público. Ainda que uma carta ou um manuscrito tenha sido adquirido por compra, tal fato "não confere ao adquirente qualquer dos direitos patrimoniais do autor" ${ }^{26}$

Entretanto, há disposições na Lei de Direitos Autorais que permitem ao pesquisador trabalhar com um pouco mais de liberdade, sem ferir os direitos do autor. $\mathrm{O}$ artigo 46 , inciso II da referida lei, diz que não constitui ofensa aos direitos do autor: "a reprodução, em um só exemplar, de pequenos trechos, para uso privado do copista, desde que feita por este, sem intuito de lucro". O inciso in esclarece igualmente que não constitui ofensa aos direitos do autor "a citação em livros, jornais, revistas ou qualquer outro meio de comunicação, de passagens de qualquer obra, para fins de estudo, crítica ou polêmica". De acordo com o inciso viII, é permitida "a reprodução, em quaisquer obras, de pequenos trechos preexistentes, de qualquer natureza [...] sempre que a reprodução em si não seja o objetivo principal da obra nova”. E, segundo o artigo 47, as paráfrases e paródias são livres.

Newton Teixeira dos Santos, um dos estudiosos do assunto, ensina: "Assim é que, por exemplo, cartas existentes em arquivos podem ser reproduzidas e utilizadas sem intuito de lucro" ${ }^{27}$ Entretanto, o mesmo autor, em texto apresentado no

25 Além das obras em relação às quais decorreu o prazo de proteção aos direitos patrimoniais, pertencem ao domínio público: as de autores falecidos que não tenham deixado sucessores e as de autores desconhecidos, ressalvada a proteção legal aos conhecimentos éticos e tradicionais (art. 45).

26 Art. 37 da Lei de Direito Autoral.

27 SANTOS, Newton P. Teixeira dos. A carta e o crime. In: Revista de Informação Legislativa, n. 108, p. 217-18, out./ dez. 1990. 
I Simpósio Nacional de Políticas Arquivísticas, realizado em Ouro Preto, junho de 1996, em resposta à pergunta "Pode um pesquisador citar uma carta?", diz que não se pode "extrair trecho de uma carta e citá-lo, mesmo que mencione a fonte, por não se tratar de texto editado".

Trabalhar com cartas missivas requer cautela, pois há que se resguardar o direito daqueles que nos confiaram sua documentação. Este é um ponto de reflexão das atividades desenvolvidas no Arquivo-Museu de Literatura Brasileira da Fundação Casa de Rui Barbosa. A política do Arquivo é a de reservar documentos, atendendo sempre a dois aspectos. O primeiro, a vontade expressa do doador, antes ou depois da doação. Como exemplo, podemos citar o arquivo do editor José Olympio, doado à Fundação Casa de Rui Barbosa, em 1979. Depois do arquivo inventariado, e decorridos quatro anos, o próprio José Olympio, por razões puramente pessoais, decidiu fechar o arquivo à consulta até 10 de dezembro de $1992,{ }^{28}$ data em que completaria 90 anos. Entretanto, em março de 1991, os seus herdeiros franquearam a consulta ao arquivo. Como já mencionamos, Pedro Nava doou sua correspondência com Mário de Andrade já lacrada. Paulo Gurgel Valente, filho de Clarice Lispector, depois de algum tempo decidiu que as cartas de seu pai, Mauri Gurgel Valente, remetidas à sua mãe deveriam ficar reservadas até o ano 2010. E Fernando Sabino, em 7 de abril de 2000, vedou o acesso a qualquer carta de sua autoria, mesmo para simples consulta.

Além deste aspecto da vontade expressa, temos muito cuidado no que diz respeito à proteção à intimidade, à vida privada. Dentro deste item levamos sempre em conta fatos relacionados à saúde, à vida familiar, amorosa, profissional e financeira, não só do titular como também de terceiros. Toda correspondência que chega a nossas mãos é lida e, sempre que nos deparamos com algum problema, consultamos o doador.

Carlos Drummond de Andrade, na crônica "O quarto violado do poeta", publicada no Jornal do Brasil de 2 fevereiro de 1978, abordou o problema do direito à privacidade.

28 A carta que solicita para que o acervo seja reservado é de 18 de julho de 1983. 
A Mário Quintana, em Porto Alegre: Estou solidário contigo e acho que todos os nossos colegas devem estar. Tua liberdade foi atingida em ponto supostamente menor, porém dos mais delicados; o direito à intimidade, que hoje extravasou dos dicionários e se chama privacidade. $\AA$ tua revelia, e contrariando tua discrição, penetraram em teu quarto de hotel e filmaram a singeleza de tuas coisas domésticas. E querem exibir o teu quarto num festival de cinema, sob um título de intragável mau gosto. Chamando a isso de homenagem.

Ainda a este respeito, o Código de Ética, aprovado pelo Comitê Executivo do Conselho Internacional de Arquivos durante o xiII Congresso Internacional de Arquivos realizado em setembro de 1996, em Beijing, assim se pronuncia: "Os arquivistas defendem o respeito à vida privada das pessoas que estão ligadas à origem ou que são a própria matéria dos documentos, sobretudo daquelas que não foram consultadas quanto à utilização ou ao destino dos documentos".

No que diz respeito aos direitos autorais, o nosso pesquisador é informado sobre a legislação vigente e sobre os procedimentos que deve cumprir para ter seu trabalho publicado sem problemas legais. Sugerimos àqueles que forem pesquisar em acervos que, sempre que possível, peçam autorização aos herdeiros do titular, informando sempre qual o objetivo de sua pesquisa e solicitando igualmente autorização para reprodução. Salientamos ainda que, para a publicação de um trabalho, seja ele acadêmico ou não, é necessária a autorização do signatário da carta, pois é ele que detém o direito autoral.

Em resumo, aquele que trabalha com cartas deve ter consciência do direito da sociedade à informação, mas deve saber também que o cidadão tem direito à privacidade.

Eliane Vasconcellos é doutora em Literatura Brasileira, chefe do Arquivo-Museu de Literatura Brasileira da Fundação Casa de Rui Barbosa e professora titular do Centro de Ensino Superior de Juiz de Fora. 